\title{
A Conceptual Framework for the Application of Corporate Social Responsibility (CSR) in the Management of Housing Projects in Nigeria
}

\author{
Afam Mike Achoru ${ }^{1 *} \quad$ Emmanuel Achuenu ${ }^{2}$ Daniel Maren Mallo ${ }^{1}$ \\ 1. Dept. of Estate Management, Faculty of Environmental Sciences, University of Jos, Nigeria \\ 2. Dept. of Building, Faculty of Environmental Sciences, University of Jos, Nigeria
}

\begin{abstract}
The Nigerian housing project setting has been marred with challenges which have continuously led to project under-performance and failure. Corporate social responsibility (CSR) is presented as a strategy to mitigate the challenges. CSR which deals with housing project firms' responsibilities in service delivery towards shareholders, stakeholders and society comprises a landscape of theories. The absence of CSR application towards solving housing project life cycle challenges presented a gap which informed the study. Variables are presented in a suitable and explored framework with a view to examining the potentials of CSR as a panacea to the challenges. This study presents stakeholder and ethical theories as the underpinning theories for the application of CSR in the management of housing projects along the project life cycle phases. Stakeholder theory states that firms' owe a responsibility to a wider group of stakeholders, other than just shareholders. Ethical theory of CSR applies to housing projects as ethics help to guide the practice of various stakeholders involved in the process of housing project management. Methodology used was a review of documented evidence from related literature. This study found that CSR application in Nigerian housing projects, although rudimentary has yielded positives when implemented. Proper CSR application in housing projects has the capacity to mitigate housing project challenges across each project life cycle phase. This study also recommends the proposition of CSR application in effective housing project management as a standard being a panacea to existing challenges.
\end{abstract}

Keywords: Corporate social responsibility, Housing project, Theories, Framework

DOI: $10.7176 / \mathrm{CER} / 12-6-04$

Publication date: June $30^{\text {th }} 2020$

\section{Introduction}

In consideration of the many challenges facing the housing project setting in each phase of the project life cycle, which has always been detrimental to project success as well as economies of many nations, the need to restrategize in projects has become ever more important. This strategy is one which is targeted to ensure that housing project firms' act responsibly in their routine project requirements. There exists a school of taught which propounds that responsible practices in the initiation, planning, design, execution and commissioning of housing projects can play a major part in the project outcome in the areas of timely conclusion, shareholder satisfaction, stakeholder satisfaction and profitability. A firm acting responsibly is termed Corporate Social Responsibility (CSR). The CSR field presents not only a landscape of theories but also a proliferation of strategies which has been harnessed towards tackling various challenges as well as improving service delivery. The rationale for CSR application in the management of housing projects as a panacea to project challenges is about housing project firms entrenching the concept of CSR in their everyday service delivery. This rationale totally hinges on the adoption of stakeholder and ethical theories which creates a possibility for firms to act responsibly and ethically by adopting and applying the concept of CSR in all phases of the housing project life cycle. Also, acting responsibly in the management of housing projects can be guided by the position of Bojar (2007) who advanced that CSR needs to pay attention to nine areas which include ethics; governance; transparency; business relationships; financial return; community involvement; product value; employment practices and environmental protection. Various malpractices have occurred during the management of housing projects and can be corrected through effective CSR application and practice (Yun \& Lee, 2011). Some of these malpractices include cheating; site theft; supply of sub-standard materials; under-utilisation of materials supplied; poor material mix etc. Avoidance of these malpractices can enhance firms' profitability, shareholder and stakeholder satisfaction to include legality in the management of housing projects hence the need for effective CSR adoption and implementation in the management of housing projects.

\subsection{The Study}

The research critically evaluates CSR and its application in the management of housing projects towards the mitigation of housing project challenges that has continually marred the housing project setting as well as the economies of many nations including Nigeria. The methodology used for the study was basically the review of documented evidence from literature. The aim of this work was to develop a framework to effectively guide the 
application of CSR in the management of housing projects along the life cycle phases, as a panacea to the ever existing housing project challenges which has continuously marred the housing project setting in Nigeria. The challenges facing housing projects were outlined. The strategies in the implementation of CSR in the management of housing projects were also enumerated with a view to adopting CSR as a panacea.

\section{Review of Related Literature}

Related works on housing project challenges and CSR application in housing projects in the aspects of: challenge categories; effect of challenge impact; CSR adoption; CSR strategies; CSR drivers and barriers; challenge mitigation levels; effect of CSR on project outcome in the developed world and so on was reviewed with the aim of defining and determining the key variables and how they interact for framework development. These were achieved under the headings:

\subsection{Challenges of Housing Projects}

A "challenge" is something that needs an elevated level of mental or physical effort in order to be overcome successfully, which also tests a person or group of people's ability. Challenges can be detrimental to the outcome of an event if not properly tackled. A major set-back facing the management of housing projects is the challenges that keep occurring during the course of management. Researchers have studied trends in housing projects with a view to collating different challenges in various societies in the past. A few of the challenges that have negatively affected success levels in housing projects include: poor housing project sensitisation; poor resource mobilisation; inadequate amenities; poor attitude of project stakeholders; inadequate project financiers; poor planning, poor scheduling to include poor organisational framework (Zami \& Lee, 2010). Emerole (2002) posited that housing development in Nigeria has fallen short due to: unrealistic expectations from project partners; erratic contract negotiations; faulty project documentation; the death of a housing development financier; weak project initiatives; low government assistance in housing projects and the inability to pay contractors and employees. Ibem and Amole (2010) advanced project challenges to border on: the poor attitude of project stakeholders; poor project fund allocation; poor project supervision and control; weak devolution of project activities; misuse of time and poor progress evaluation. Nwosu (2010) submitted that over the years, Nigeria housing projects have suffered in the past due to: weak project policies to include erratic housing project contract negotiations; constant site accidents; religious and tribal conflicts and poor infrastructure and layout. Abdellatif and Othman (2006) researched and found the following challenges as being detrimental to the success and sustainability of housing projects: lack of feasibility study; lack of viability study; failure to define a project early enough; poor resource distribution in a project setting; faulty project forecasting; poor project budgeting; imminent diversion of project funds and inflation of contract quotes.

Bearing in mind the above listed challenges and their tendencies to negatively impact on success levels in the course of executing housing projects in each phase of a project life cycle, Ibem and Aduwo (2015) advanced that housing projects employed some strategies such as better project fund management plans; an improved project site accessibility; an improved infrastructure; the use of better professionals and technical abilities in housing projects; proper screening of building plans prior to housing projects and the supervision of material procurement and delivery which all contributed positively but still underperformed towards mitigating some challenges. In a study in Tanzania, Kavishe (2018) found that the use of routine inspection teams have often necessitated the monitoring of PPP housing project sites and in some other cases, the use of direct and indirect labour has all been employed towards the mitigation of housing project challenges. An improved screening of labour and materials; adequate labour transportation to and from site; an enhanced materials management and proper utilization and monitoring of construction equipment are some of the strategies employed towards solving housing project challenges to guarantee project success (Nwosu, 2010). Landon and Alken (2012); Aaltonen and Kujala (2010) postulated that strategies such as regular stakeholder engagement and routine performance checks during the phases of projects have been used to limit housing project challenges which still persist. Jiboye (2009) submitted that as a means to efficiently mitigate housing project challenges, proper layouts, improved infrastructure and social amenities were often put in place prior to housing projects to ensure project success and in some cases, the projects still fell short of requirements and even failed. These strategies all contributed their quota towards effective housing project management but nevertheless, persistent challenges greatly affected success levels of housing projects in either or all of the life cycle phases which has undermined project outcomes over the years. In order to attain the much needed efficient and effective Nigerian housing project with a decline on project setbacks, there is a need to restrategise. Strategies tend to open up new pathways and targets towards ensuring a hitch free process. CSR is a strategy that can be properly harnessed in Nigerian housing projects considering that it has the capacity to deliver high success levels as found in the developed world, hence the need to design and propose a framework for its application in the Nigerian housing projects setting. 


\subsection{The Need for CSR in Housing Project Management}

CSR is seen as a strategic tool to generally achieve economic objectives to include wealth creation (profitability) in the management of housing projects. CSR has a long tradition and have enjoyed a wide acceptance in service provision which visibly exists in the management of housing projects. As Windsor (2001) pointed out, a general belief of profit and wealth creation has progressively dominated the managerial conception of firms' responsibility which drives the shareholder theory. Profitability is good and acceptable to firms' investments, but profitability without social actions can impact on a firm negatively in the long run. This then means that concern for profits should not exclude taking into account the interests of all who have a stake in a housing project (stakeholders). A way to achieve this is by integrating the elements of ethical, philanthropic, economic and legal responsibilities into housing project management (Blome, 2012).

Sung (2015) listed economic responsibilities in a housing project to centre on: generating profit for housing development firms; paying employees wages promptly; payment of taxes when due; investment and re-investment for profit generation; effective budget planning; budget adherence and loan schemes. Legal responsibilities bother on: managing activities of housing projects within the confines of country law; educating employees on the requirements of the law; obeying labour and tax laws; proper project contract/agreement documentation; to include engaging the services of qualified legal luminaries (Sung, 2015). Sung (2015) also highlighted ethical responsibilities which border on: reviewing employee wages; enhancing benefits for employees; avoidance in dealing with unscrupulous clients; suppliers and contractors in housing projects; offering employment when needed; avoidance of corruption and cheating during housing project tendering activities; paying contractors and suppliers duly; adopting the use of quality material and equipment during housing project; ensuring a conducive housing project work environment; ensuring health and safety standards in housing projects; assisting in staff accommodation and transportation, setting up housing project conflict resolution mechanisms and ensuring that housing projects are environmental friendly in avoiding air, land, noise and water pollution. According to Sung (2015), the philanthropic responsibilities deal with: societal donations by the housing project developers; charitable actions; engaging in community service and creating programs which ensure the ability to give back to society.

Yam (2013) posited that the application of CSR in housing projects will enhance shareholder satisfaction (profitability), stakeholder enhancement and societal acceptance of firm and project. It has also been argued that in certain conditions, the satisfaction of some interests can contribute to maximising shareholder as well as stakeholder values (McWilliams \& Siegel, 2001; Odgen \& Watson, 1999) which drives the stakeholder theory of CSR. An adequate level of investment in philanthropy and social activities should also be acceptable for not only the sake of profit to housing project management firms but to be widely accepted and respected in society (Preston, 2005). Yun and Lee (2011) opined that the management of housing projects should be such that shareholder and stakeholder interests should be given equal priority. This then means that strategies for profitability in a housing project firm should be directed towards satisfying interests across board.

In practice, a number of studies have been carried out to determine a correlation between CSR and corporate success of firms. Of these, an increasing number show a positive correlation between the social responsibility and enhanced performance of firms in most cases (Moore, Slack \& Gibbon, 2009. This basically means that CSR can be conveniently applied in the management of housing projects provided it is done with the aim of satisfying shareholder and stakeholder interests without affecting project performance. Griffin (2000) however warned that these findings have to be absorbed with caution since such correlation is difficult to measure. The application of CSR in housing projects in a focussed, coordinated and strategic manner can strengthen this correlation regardless of anticipated measurements. Ultimately, CSR strategy will be unique for different housing project management firms (Lomano, 2010). Pressures of the market along with the characteristics and norms of particular industries have an effect on the costs and anticipated gains in implementing CSR (Stratling, 2007). This is clearly visible in housing projects as project performance as well as profit margin is largely dependent on shareholder and stakeholder effect as well as the nature of market for materials or end product. Before undertaking any CSR strategy, housing project management firms may need to thoroughly consider the effects of such actions as they will eventually affect housing projects profitability and stakeholder satisfaction (Miller, 2015). In a study, Galbreath (2009) found that stakeholders react negatively to negative CSR strategies, whereas only those most supportive of the CSR issues react positively to positive CSR strategies. In order to achieve project satisfaction, positive CSR strategising in housing projects should adhere to Carroll (2004) guiding principles of CSR which are: accountability; transparency; ethical behaviour; respect for stakeholders; respect for the rule of law; respect for international norms, behaviour and human rights. With the use of the guiding principles, housing project firms' then have the responsibility to figure out what strategies that would work in its different projects.

The successes realizable in housing projects are also largely dependent on the quality and experience of a project manager and team (Zami \& Lee, 2010). Yam and Mcgreal (2010) advanced the importance of quality managerial roles for CSR in housing. Baron (2007) posited that to attain success, managers should only pursue CSR actions that are widely and strongly supported by firms and once CSR programs are initiated, firms should assess their success, anticipated profitability and service utility. As a result, managers need to avoid perceptions 
of social irresponsibility as it can greatly impact negatively on housing project profitability. Housing project management firms must determine CSR expectations in the communities in which they operate as it helps to determine the finesse in the flow of the project requirements which will in turn influence success (Preston, 2005). The housing project firm's view of CSR and the community's view of CSR may be misaligned which can affect project success hence the need to often review CSR strategies between housing projects.

\subsection{Changing Public Expectation of Housing Project Management Firms}

Reciprocity between firm and society should exist in the management of housing projects for the purpose of solving project challenges and to attain a two faceted success levels. Globally, it has been established that firms are expected to do more than just provide jobs and contribute to the economy through taxes and employment (Mackey, Mackey \& Barney, 2007). Clients, stakeholders and society in general expect more from these housing project firms whose services they require and engage in without considering a reciprocal action to encourage housing project activities. Some of the expectations of society from housing projects centre on philanthropic responsibilities in housing projects which include: societal donations by the housing project developers; charitable actions; engaging in community service and creating programs which ensure the ability to give back to society. Others also border on legal responsibility which ensures that the law is followed in housing projects by: managing activities of housing projects within the confines of country law; educating employees on the requirements of the law; obeying labour and tax laws; proper project contract/agreement documentation; to include engaging the services of qualified legal luminaries. Expectations should equally be anticipated by way of housing project firms from society which borders on the creation of an enabling environment for housing project operation. In line with this, Epstein (1999) posited that coherency exists in entrenching the idea that social actions benefit society and hence mandates a reciprocal action. This reciprocal action can then be applied to the management of housing projects by engaging responsibly in project practices on one hand and expecting the society to equally cooperate with the housing project firms' practices on the other. In addition, special consideration can be given to the trend of continuously occurring corporate scandals and malpractices mentioned earlier which is clearly aided by society and affects housing project performance. Public can play a role in re-establishing and affirming confidence in the ability of regulatory bodies to check and control corruption excesses as they affect housing project performance (Ademiluyi, 2010). This has led to an increasing expectation that practices in housing projects should be more open, accountable and better prepared to engage appropriately on their performance in social and environmental arenas (Yam, Ismail \& Tan, 2008).

\subsection{Conceptualising on Housing Project Management Firms' CSR Adoption}

As the application of corporate social responsibility is crucial in the management of housing projects towards tackling project challenges, it is equally vital for firms to conceptualise on its adoption with a view to achieving timely and quality project goals. Preston (2005) advanced that in a society where housing project management firms strive for a unique means of providing service to differentiate themselves from their competitors, CSR initiatives enable housing project management firms to build a stronger status that resonates with key external stakeholders, clients, general public and the government. Building stronger status is guided by economic responsibilities in a housing project which centres on: generating profit for housing development firms; paying employee wages promptly; payment of taxes when due; investment and re-investment for profit generation; effective budget planning; budget adherence and loan schemes. This helps to attract better status as well as target future bigger projects in almost every sector. Management of housing projects presents itself as a major pathway for establishing and sustaining a wonderful reputation for firms considering that houses last a lifetime (Jonna \& Dean, 2012). It is mandatory that housing project management firms recognise that adopting an effective CSR approach to managing housing projects can open up new opportunities and increasingly contribute to the firm's ability to attract passionate and committed stakeholders to be able to deliver on corporate goals which are basically profitability and social responsibilities (Yun \& Lee, 2011). This can be accelerated by these ethical responsibilities in housing projects: reviewing employee wages; enhancing benefits for employees; avoidance in dealing with unscrupulous clients, suppliers and contractors in housing projects; offering employment when needed; avoidance of corruption and cheating during housing project tendering activities; paying contractors and suppliers duly; adopting the use of quality material and equipment during housing project; ensuring a conducive housing project work environment; ensuring health and safety standards in housing projects; assisting in staff accommodation and transportation, setting up housing project conflict resolution mechanisms and ensuring that housing projects are environmental friendly in avoiding air, land, noise and water pollution.

The overall impact of a firm is noticed by the service it renders through CSR in the directions of: its recruitment and training processes; its adherence to rights and values; its environmental impact; its investment in the project community (Zinczuk, 2012). CSR in the construction industry extends in many directions which can help the construction industry. Well designed houses can improve quality of life, which in turn promotes good health and this can be achieved through CSR (Yun \& Lee, 2011). Community design and construction can affect 
the social life of the residents and can even lower crime rates. Infrastructural amenities such as very well-lit road network, paved bike trails and paved jogging paths with good visibility amongst many others can attract a wider societal satisfaction through CSR approach. Effective housing project execution influences employees; suppliers; home buyers; communities and even the government (Leffat, 2012). The effective implementation of CSR in housing projects would give benefits to several groups which include the housing project firm itself, the community and the environment (Preston, 2005). Holmes (2002) found the following benefits of effective adoption of CSR in housing development: the increase in the commitment and motivation of employees; creating an organisational culture that enhances future developments; lowering the cost of supervision, to include enhancement in innovation and profit. CSR in housing projects can also lead to avoidance of some barriers which include: an increased cost constraint; a decreased awareness of CSR implementation; decreased human resource; a decrease in employee motivation; a decrease in top management commitment; a decreased understanding of CSR concept; enhanced duplication; increased over-emphasis on inspections and cheating; poor CSR technology usage and time resource management.

\subsection{CSR Policies and Strategies for Housing Projects}

For decades, corporate social responsibility has been a subject of intense debate among scholars and professional service providers (Windsor, 2001). Discussions have generally focused on the role of business in society and the nature of a firm's social responsibilities. More recent investigations have progressed towards theory development as well as empirical tests of the relationship between CSR and firm performance (Chen, 2011). Various policies are often required in real estate and related developments. CSR Policies and strategies in a corporate world are about how firms adopt and implement CSR into their policies and plans in order to better their operations. This can be done by integrating vision with policies alongside strategies, by involving internal and external stakeholders and their present and future needs and expectations in the development, review and update of policy and strategy (Galbreath, 2009). Corporate leaders of housing projects need to be mindful of the competitive and profit advantages that can be reached through a proper strategy that include social responsibility.

Lomano (2010) posited that a CSR strategy in housing projects involves: overall direction for where the housing project management firm wants to take its CSR structure; care for stakeholders and their respective interests; a basic approach for moving the housing project ahead; specific housing project priority areas; a time line for action; use of responsible staff and a process for reviewing and assuring outcomes. To develop a CSR strategy, a housing project management firm should: build support with the shareholders; senior management and employees; research on what other housing project firms (competitors) are doing with the aim of assessing the value of recognised CSR instruments; prepare a matrix of proposed CSR housing project actions; develop options for proceeding with the project and decide on direction, approach, boundaries and focus areas (Preston, 2005). Mackey, Mackey and Barney (2007) posited that during steps in developing a CSR strategy, it is important to identify the specific benefits that can be brought into a firm. Stratling (2007) noted that during the process of strategising, the firm should be able to deal with questions like: in which way can a CSR strategy contribute to the firm's objectives? How can a firm intertwine these objectives with the ongoing developmental progress? And, how can a CSR strategy assist the firm in obtaining skilled and diverse workforce in the future? To connect CSR to the housing project management firms' strategy, it is also important for a firm to define what it means when using the definition CSR.

At a practical level, there appears to remain much confusion with respect to how to build or integrate CSR into the overall strategy of a housing project management firm. Usually where efforts are made with respect to CSR strategies, typical approaches can be weak in that they may fail to capture the fundamental purposes of the strategy. Bojar (2007) posited that typical approaches by way of strategy of CSR in projects include: effectively developing corporate codes of ethics; preparing triple bottom line reports and launching public relations campaigns that highlight a given socially responsible act.

\subsection{Overview of Existing Frameworks on the Application of CSR in Housing Projects}

The need for corporate social responsibility cannot be over emphasized which have ensured its successful application in several integral areas of countries economy. One major and versatile area which has accommodated the application of CSR is the construction industry. A very common aspect of the construction industry which has been influenced through CSR adoption and implementation is housing project management. Studies on the multidimensional nature of housing projects present an array of frameworks which have influenced outcomes as well as project success and sustainability. Mia and Othman (2007) in a study created a framework for the integration of CSR in the practices of quantity surveying firms as an approach for solving housing construction problems in South Africa by identifying each area of improvement and integrating CSR as a strategy. Findings indicate that the framework can possibly achieve high performance and success levels in quantity surveying practices. In consideration of the importance of stakeholder interest in a housing project setting, Senawi, Abdul-Rahman, Mohammed and Pin (2016) came up with a model for stakeholder engagement and welfare through CSR in housing 
projects as a way to improve stakeholder interest as well as productivity in housing projects. Lomano (2010) noted stakeholder pressure as being detrimental to housing project success in Chile and developed a CSR model for determining stakeholder pressure and firms' reactions to augment the pressure. Also on stakeholder welfare, Yam (2013) attempted to enhance the practice of CSR in housing project by creating a framework with an ethical and philanthropic inclination for housing development for construction employees as found that CSR adoption helped housing projects. Furthermore, Ojo and Oladokun (2013) advanced the socially responsible property development (SRPD) model which is a framework targeted at reducing the negative impact on buildings and structures with CSR from the views of human health, natural environment waste reduction and pollution. Yun and Lee (2011) studied around finances and its importance in housing project management in Singapore and proposed a model for enhanced financial management through CSR implementation.

Furthermore, Preston (2005) observed pressures on housing project firms' by county representatives in Australia, which influenced project performance negatively and therefore came up with a framework for resultant actions by project firms on county influences during housing projects. The study found positive inclination towards the reduction of pressures with CSR strategies which ensured due project delivery and better relationships. Sung (2015) advocated for partnership in Hong Kong housing projects which led to the proposition of the CSR partnership framework which was a model for enhancing partnership among contractors in a multi-contracted housing project. A framework for maintaining high performance in Australian housing projects by integrating CSR also achieved success (Petrovic-Lazarevic, 2009). For the purpose of housing marketability and sustainability, Yam, Ismail and Tan (2008) advanced the creation and proposition of a model for Malaysian housing developers to use in for integration of CSR in housing development for the benefit of housing project marketability to include sustainable housing development.

Each of these frameworks targeted the enhancement of certain aspects of housing projects through CSR. Also, findings on CSR application in housing projects in these studies which were objective in nature and all conducted in various nations had a possibility of differing from similar studies in Nigeria with rudimentary CSR practices due to: policies; cultural differences; religion; politics and difference in technology hence the need to investigate its application in Abuja, Nigeria. However, the application of CSR towards the mitigation of existing housing project challenges in the phases of a housing project life cycle remained an area which was yet to be delved into despite its prospect in improving housing project management which makes it subjective in nature. Tolati (2013) suggested the rationale for focusing on CSR in developing countries to be that: developing counties have potentials for a rapidly expanding economy; social and economic crisis are usually most felt; globalization, economic growth, investment and business activities may have more social impact and they may present a distinctive set of CSR agenda which differ from the developed world hence, the need for a framework for the effective implementation of CSR in managing housing projects towards mitigating challenges in the phases of a housing project life cycle became imperative. The process of applying CSR as a strategy in managing housing projects was guided by the stakeholder and ethical theories.

\section{Development of Conceptual Framework}

A conceptual framework explains the overall structure for undertaking a research. This work focuses on the management of mass housing projects with the application of the concept of CSR particularly in the phases of a housing project life cycle. The theories which underpin this study are the stakeholder or integrative CSR theory and ethical CSR theory. The complexities and challenges relating to housing project management in the phases of the housing project life cycle drive the CSR stakeholder theory. Several types of challenges have marred the performance levels of housing projects hence the need for a corrective action in the form of applying CSR in housing projects. The CSR stakeholder theory ensures that stakeholder interest at every phase of the housing project life cycle is most considered as a panacea to the challenges towards ensuring the maximisation of output during the course of the management of housing projects. Despite this, moral principles must be imbibed alongside decency and integrity in the activities of housing projects especially the management aspect hence the ethical theory of CSR. The ethical theory of CSR encourages the fact that housing project management firms are ethically responsible to stakeholders and society by acting responsibly in their activities and should adopt such ethical practices in decision making and operations in the management of housing projects across housing project life cycle phases. The ethical dimension of most firms in practice is to embed ethical, philanthropic, legal as well as economic responsibilities in service delivery (Baron, 2007). The stakeholder and ethical theories both ensure that housing project stakeholders (employees, community, suppliers and shareholders) roles is redefined in housing project management taking into account the broader responsibility towards society and environment, beyond economic performance. These theories can also evaluate whether firms' conduct their operations in an ethical manner using ethical, philanthropic, legal and economic responsibilities as a yardstick.

A diagrammatic conceptual framework is designed for the application of CSR as a panacea to housing project challenges which hinges on subjectivity. A CSR principle in the management of housing projects is that which ensures that stakeholder and ethical theories are inculcated in housing projects, and this study adopted a subjective 
approach. In the context of managing housing projects with CSR application, CSR was essentially strategic in tackling housing project challenges faced in the life cycle phases of housing projects. As a representation of the independent variables, some of the initiation phase challenges indicated include: poor forecasting; lack of feasibility studies; weak project policies; poor project budgeting and poor resource control. Some of the planning phase challenges include poor scheduling; poor planning; poor site allocation; poor choice of contractors and poor resource distribution. A few of the design phase challenges are: inappropriate design; faulty design; uneconomic design; poor design interpretation and late design delivery. The represented execution phase challenges are; poor supervision; poor workmanship; wastage of materials; delay in supplies and site accidents. Commissioning phase challenges are: poor progress evaluation; poor management; misuse of time; poor communication and delay in handover.

The adoption of drivers to successful CSR implementation and barriers mitigating CSR implementation are also importantly considered. Drivers in the implementation of CSR in housing projects which include: good CSR objectives; detailed CSR plan; use of competent managers; good leadership; client support; competitiveness; charitable activities and openness to learning, should be strictly adhered to. Also, barriers to the implementation of CSR in housing projects which include: poor monitoring and control; improper budget; corruption; political instability; inadequate human resource and cheating should strongly be avoided. A solution to housing project challenges was proposed to be achieved by the adoption and implementation of CSR in project life cycle phases through strategies such as: paying wages promptly; effective budget planning; obeying the law; use of proper project contract agreement; review of employee wages; avoiding corruption and cheating; societal donations and charitable actions amongst others, which all fall under the ethical, philanthropic, legal as well as economic responsibilities of CSR in the management of housing projects. The requirements of these four responsibilities should be keenly followed to achieve high challenge mitigation levels in ensuring housing project performance and success. Management of housing projects with CSR application is anticipated to realise as the dependent variables: the ability to obey the law during projects; efficient housing cost; quality housing; an enhanced housing project delivery; an increased number of housing units across several projects; shareholder satisfaction; stakeholder enhancement; improved housing project management firms' reputation and standing; generate positive publicity as well as enhance the relevance of CSR in managing housing projects as presented in the figure below.

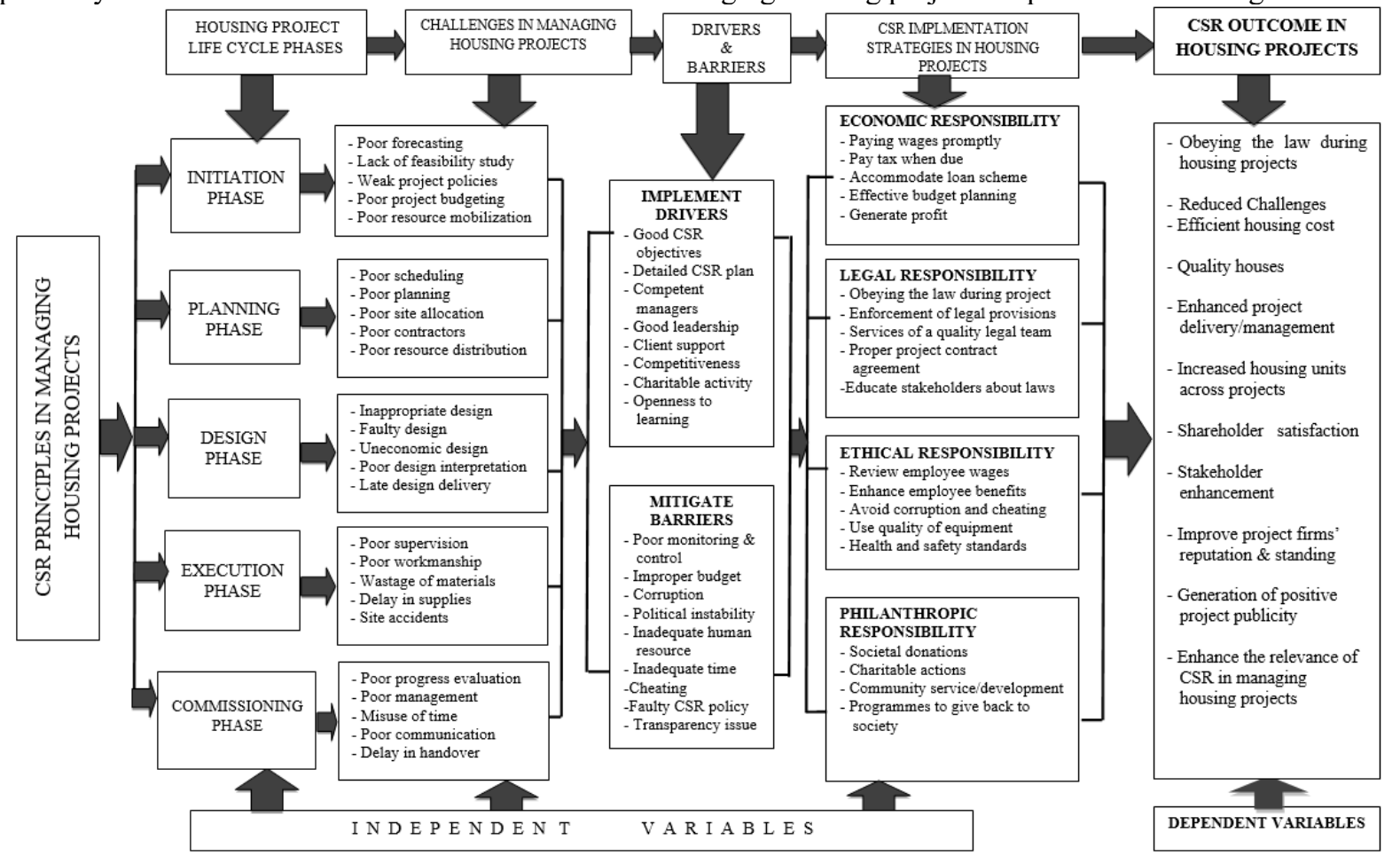

Figure: A Conceptual Framework for the Application of CSR in Housing Projects

Source: Authors Construct, 2019.

\section{Findings}

Findings from the study revealed that numerous challenges exist in the course of managing housing projects which has marred project performances. These challenges exist in all housing project life cycle phases and have become detrimental to project success. Despite various attempts at mitigating the challenges, they still persist thereby undermining the effort, performance and sustainability of housing projects. Rapidly growing firms' are actively 
engaged in CSR practice all round the world. Furthermore, CSR application in the management of housing projects is still rudimentary in the developing nations. Also, there was no standardised CSR framework for the management of housing projects through the application of CSR despite CSR being applied in various aspect of housing construction. The created framework totally hinges on the adoption of stakeholder and ethical theories of CSR which creates a possibility for firms to act responsibly and ethically by adopting and applying the concept of CSR in all phases of the housing project life cycle. Many Nigerian firms believe in the importance of CSR but had little or no strategy documents or policies to guide CSR in their practices.

\section{Conclusion and Recommendations}

The aim of this study was to develop a framework for the application of CSR in the management of housing projects as a panacea to housing project challenges. This research methodology centred on the review of documented evidence from literature. An overview of past frameworks was also studied and highlighted. CSR has been applied in a multitude of ways in the construction industry but has never been used to mitigate housing project challenges especially along the project life cycle phases which necessitated this study. The rationale for corporate social responsibility application in the management of housing projects is about housing project firms entrenching and applying the concept of CSR in their everyday service delivery. A framework for the application of CSR in the management of housing projects was developed which captured the main variables that will ensure success in the mitigation of challenges through CSR. The themes included housing project life cycle phases; housing project challenges along the life cycle phases; drivers and barriers to a successful implementation; CSR application strategies along the responsibilities and the anticipated outcome from the application of CSR.

In view of the challenges being faced during housing project management, the following recommendations were offered for its improvement: housing project firms' should adopt and implement CSR strategies in the management of housing projects; firms may adopt strategies for different housing project settings depending on the nature of the project or the project location or the religious and cultural beliefs of the host community; there is also a need to bring coherence in the manner of CSR strategies and how to measure and report on social and environmental values timely; firms' are advised to engage in some charitable activities within a stipulated budget to ensure project smoothness and acceptance within the host community; a CSR action plan should be created post housing project to successfully guide the project; firms need to treat stakeholder responsibilities as important as shareholder responsibilities in a housing project; firms should develop CSR policies as working documents and housing project firms' need to review their CSR policies periodically to ensure its relevance in changing times.

\section{References}

Aaltonen, K. \& Kujala, J. (2010), “A Project Lifecycle Perspective on Stakeholder Influence Strategies in Global Projects". Scandinavian Journal of Management, Elsevier, 26:381-397.

Abdellatif, M.A. \& Othman, A.A.E. (2006), "Improving the Sustainability of Low Income Housing Projects: The case of Residential Buildings in Musaffah Commercial City, Abu Dhabi”, Emirates Journal for Engineering Research, 11(2), 47-58.

Ademiluyi, I.A. (2010), "Public Housing Delivery Strategies in Nigeria. A Historical Perspective of Policies and Programmes", Journal of Sustainable Development in Africa, 12, (6) 153-161.

Ademiluyi A. I. \& Raji, B. A. (2008), "Public and Private Developers as Agents in Urban Housing Delivery in Sub- Saharan Africa: The Situation in Lagos State", Humanity \& Social Sciences Journal, 3(2) (2008), 143150.

Adenuga, O. A. (2013), "Factors Affecting Quality in the Delivery of Public Housing Projects in Lagos State, Nigeria", International Journal of Engineering and Technology, 3 (3), 332-344.

Baron, D. (2007). Corporate Social Responsibility and Social Entrepreneurship. Journal of Economics \& Management Strategy, 16(3), 683-717.

Blome, G. (2012), "Corporate Social Responsibility in Housing Management: Is It Profitable? Property Management”, 30(4), 351-361.

Bojar, M. (2007), “Corporate Social Responsibility”, University of Technology Press, Lublin.

Carroll, A.B. (2004), "Managing Ethically With Global Stakeholders: A Present and Future Challenge", Academy of Management Executive, 18(2), 114-120.

Chen, H. C. (2011), “The Major Components of Corporate Social Responsibility”, Emerald Group Publishing Limited. Asian Institute of Technology, Klong Luang, Thailand.

Emerole, C.G. (2002), "Restructuring Housing Development and Financing in Nigeria: The Role of Partnership and Collaboration Strategies Housing Today", The Journal of the Association of Housing Corporations of Nigeria $(A H C N), \mathbf{1}(5)$ : 26-29.

Epstein, E. (1999), "The Continuing Quest for Accountable, Ethical and Humane Corporate Capitalism", Business and Society, 38(3), 253-267.

Galbreath, J. (2009), "Building Corporate Social Responsibility into Strategy”, European Business Review, 21 (2), 
109-127.

Griffin, J. J. (2000), "Corporate Social Performance: Research Directions for the 21 st Century", Business and Society, 39(4), 479-493.

Holmes, J. (2002),'The Property Dimension of Corporate Social Responsibility”, Paper Presented at ERES Conference. Glasgow.

Ibem, E.O. \& Aduwo, E.B. (2015), "Assessment of the Sustainability of Public Housing Projects in Ogun State, Nigeria: A Post Occupancy Evaluation Approach", Mediterranean Journal of Social Sciences, 6(4), 523-535.

Jiboye, A.D. (2009), "The Challenges of Sustainable Housing and Urban Development in Nigeria", Journal of Environmental Research and Policies. 4(3), 23-27.

Jonna, P. \& Dean, G. (2012), "Evaluating UK Housing Policies to Tackle Housing Affordability", International Journal of Housing Market and Analysis, 5(3), 253-271.

Kavishe, N. (2018), "Risks Associated with Public Private Partnership (PPP) Housing Projects Delivery in Tanzania”, International Journal of Construction Engineering and Management, 7(2), 81-87.

Landon, D.A. \& Alken S.D, (2012), “The Life Cycle Phases of Construction Projects: Key Issues and Solution”, Van Nostrand Reinhold, New York.

Lomano, A. (2010), “The Positives of Corporate Social Responsibility in Housing Projects”, La Sena Press, Chile.

Lefat, B.F. (2012), "Challenges associated with the Sustainable Management of a Housing Project Life Cycle: A study of Myanmar Rural”, Asian Journal of Civil Works, 11(2), 12-23.

Mackey, A., Mackey, T.B. \& Barney, J.B. (2007), “Corporate Social Responsibility and Firm Performance: Investor Preferences and Corporate Strategies", Academy of Management Review, 32(3), 817-35.

McWilliams, A. \& Siegel, D. (2001), "Corporate Social Responsibility: A Theory of the Firm Perspective", Academy of Management Review, 26 (1), 117-127.

Mia, B. \& Othman, A.A. (2007), “Affordable housing: An investigation into the corporate social responsibility of South African quantity surveying firms. Proceedings of the International Conference on Sustainable Human Settlements for Economic and Social Development, Zambezi Sun International Hotel, Livingstone, Zambia, pp. 298-315.

Moore, G., Slack., R. \& Gibbon, J. (2009), “Criteria for Responsible Business Practice in SMEs: An Exploratory Case of U.K. Fair Trade Organisations", Journal of Business Ethics, 89: 173-188.

Nwosu, C.A. (2010), “The Undermining factors of Nigeria Housing Project failures”. ABEL Printers, Aba.

Ogden, S. \& Watson, R. (1999), “Corporate Performance and Stakeholder Management: Balancing Shareholder and Customer Interests in the U.K. Privatized Water Industry”, Academy of Management Journal 42(5), 526538.

Ojo, O. \& Oladokun, T.T. (2013), "Property Development and CSR. In book: Encyclopaedia of Corporate Social Responsibility Retrieved June 7, 2018”, from https://www.researchgate.net/publication/303929211_Property_Development_and_CSR.

Petrovic-Lazarevic, S. \& Violet, L. (2009), "Corporate Social Responsibility in the Australian Building and Construction Industry”, Department of Management Working Paper Series, No. 01/09.

Preston, L.H.N. (2005), "Adopting Corporate Social Responsibility in Housing Project Delivery: A case of selected projects in Ballarat, Australia", Australian Journal of quality and reliability management, 11(4), 5667.

Senawi, A., Abdul-Rahman, N.A.Y., Mohamed, A.N. \& Pin, S.F.C. (2016), “Corporate Social Responsibility Practices among Malaysia Top Property Developers”, Conference Proceeding of the Social Sciences Research, 18 - 19 July 2016, Kuala Lumpur, Malaysia. Retrieved March 21. 2018, from https://worldconferences.net/proceedings/icssr2016/fullpapers.

Stratling, R. (2007), "The Legitimacy of Corporate Social Responsibility", Corporate Ownership and Control, 4(4), 65-73.

Sung, D.S. (2015), "Partnership as a Corporate Social Responsibility Tool for Housing Project Stakeholders". Yiang-Zi Publishing Company, Tai Po Hong Kong.

Tolati, B.N. (2013), "Modern Day Corporate Social Responsibility Application for Firms”. Recca Publishers, Dunedin New Zealand.

Windsor, D. (2001), "The Future of Corporate Social Responsibility", International Journal of Organizational Analysis, 9(3), 225-256.

Yam, S. (2013) "The Practice of Corporate Social Responsibility by Malaysian developers", Property Management, Vol. 31 (1), $76-91$.

Yam, L.H.S. \& Mcgeal, S. (2010), "House-buyers' expectations with relation to corporate social responsibility for Malaysian housing”, International Journal of Housing Markets and Analysis, 3(2), 132-145.

Yam, L.H.S., Ismail, M. \& Tan, S.Y. (2008), "Corporate Social Responsibility in Malaysia Housing Development: The Developer's Perspective", Pacific Rim Property Research Journal, 14(2), 177-198.

Yun, L.D. \& Lee, K. (2011), "New Strategies for Firms - The Implementation of CSR in Housing Projects in 
Yishun City, Singapore”, Asian Journal of Technology and Management in Construction, 3(1), 113-124.

Zami, M.S. \& Lee, A. (2010), "Misunderstanding of Housing and its Influence on the Success of Low Cost Housing Projects: State of the Art Review", The Built \& Human Environment Review, 3(1-11).

Zinczuk, B. (2012), "Corporate Social Responsibility and its Application in the Enterprise", Management, Knowledge and Learning International Conference 2012. 